\title{
Features of the Ukrainian and US Experience in the Innovative Principal Preparation
}

\author{
D. Kozlov \\ Sumy State Pedagogical University named after A.S. Makarenko, Sumy, Ukraine \\ Corresponding author. E-mail: 32012anna@gmail.com
}

Paper received 28.04.18; Accepted for publication 05.05.18.

\begin{abstract}
http://doi.org/10.31174/SEND-PP2018-165VI69-03
\end{abstract}
\begin{abstract}
The article focuses on the features of the Ukrainian and US experience in preparing school principals of innovative type. The seven key features of effective leadership preparation programs have been identified. The author focuses on Murphy's three new pillars of leadership influencing the development of the innovative programs of principal preparation. The drawbacks of the US customary approach to the principal preparation have been revealed as well. Some recommendations developed by the National Staff Development Council for the principal preparation program content to be considered in the development of programs have been outlined.
\end{abstract}

Keywords: school principal, preparation, US experience, innovation, university.

Introduction. Since school principals in a contemporary school play a dazzling array of roles, ranging from educational visionaries and agents of change to instructional leaders, curriculum and assessment experts, administrative support managers, special program administrators, budget and management analysts and community creators [3], the preparation of a school leader of innovative type in Ukraine and abroad is a daunting challenge, and critical for both school improvement and academic performance.

The relevance of the foreign experience to be learnt and implemented in the Ukrainian universities is conditioned by the fact that the principal preparation in foreign countries provides for the four types of programs such as university-based, district-based, third-party professional development organizations, and partnership programs.

Brief review of publications on the topic. The literature on the principal preparation programs provides a dichotomous view of the appropriateness and expedience of these programs for principals to work with the presentday conditions in mind. On the one hand, a vast array of this literature contends that a greater part of the principal preparation programs fail to provide intrinsic leadership opportunities [6]. Such authors as H. Peel, K. Buckner, C. Wallace, S. Wrenn and R. Evans consider that brand-new principals are equipped with theory, and overwhelmed with reality [11, p. 27]. Universities have conventionally focused on introducing potential school principals to the latest trends and theories in educational leadership, but have failed to equip them with practical skills to be applied in the real-world contexts. On the other hand, there is much literature devoted to the professional preparation programs based on the national standards, teaching and learning research, and the role of the school principal as an instructional leader [5].

The dispositions, special knowledge and skills required for effective school leadership and the formation of the school principal's focus on acquiring special skills in the management of innovative processes are studied in the works of the domestic and foreign researchers such as $\mathrm{H}$. Danchenko, H. Dmytrenko, B. Zhebrovsky, L. Karashchuk, V. Lazarev, V. Maslov, T. Panchuk, V. Pikelna, M. Potashnyk, T. Shamova, E. Hale, S. Huber, N. Moorman, J. Norton, J. Quenneville, M. Orr, C. Wallace, S. Wrenn, etc.

However, the analysis of numerous researches proves the lack of fundamental studies in the principal preparation in the Ukrainian pedagogical science. The need for practice in the effective management of school renewal, immaturity of the problem of preparing secondary school principals for the management of innovation processes, as well as difficulties in the implementation of pedagogical innovations have determined the scope of the studies conducted.

The goal of this article is to identify and analyze the advanced foreign experience in preparing school principals of innovative type.

The following research objectives are derived from the above goal:

- to characterize the progressive experience of the US universities in implementing the principal preparation programs;

- to reveal and consider the benefits and drawbacks of the principal preparation programs implemented.

Materials and methods. During the research a complex of methods, including: analysis, comparison, and generalization of scientific literature were used in order to achieve the goals to be sought. The SWOT-analysis application enabled to identify the strengths and weaknesses of the principal preparation programs.

Results and their discussion. Nowadays, the improvement in school leadership enjoys pride of place among the priorities for school reform being implemented both in Ukraine and abroad. In light of this, the preparation of an innovative principal is one of the pressing matters, and the challenge the universities face. The innovative principal preparation programs shall be designed to fulfill the vision reflecting in the national standards and develop principals with the knowledge, skills and features of an instructional leader, and the ability to give a boost to the internal and external school communities in support of increased academic attainment.

The objectives of the programs aimed at preparing principals are to train innovative and reflective leaders who will create the learning community supporting students both academically and socially, could serve as a catalyst for significant changes, create and promote social justice such as academic excellence and equity, and promote high expectations of academic progress.

In the context of this study, our appealing to the foreign experience, in particular, the experience of the US universities, in preparing innovative school principals under the Master's programs is due to the fact that in Ukraine the preparation of school principals is implemented only under the university-based programs, that is 
to say the Master's programs entitled "Educational Institution Management" or "Educational Institution Administration". The duration of these programs usually ranges from 1 to 1.5 years. The objectives of the programs are to prepare the highly qualified and socially conscious principals with professional knowledge and skills, innovative way of thinking and innovative culture, who are capable of creating the educational environment, meeting the needs of individuals, society and the state, the school leaders and educational managers who will perform an array of scientific and research, educational, academic and administrative functions in the managerial and pedagogical activities in a proper manner.

The principal preparation programs are tailored to:

- to ensure the preparation of a principal of innovative type in accordance with the needs of labor market related to the formation of competences and improvement in quality;

- to prepare the highly qualified specialists being competent in the legal and managerial issues of educational activities and being able to fulfill the tasks of organization, governance and management of the educational process at school under the present-day conditions in a professional manner;

- to prepare school leaders able to address the challenges they or school as a whole face, to formulate and promote the strategic objectives aligned with the school mission and vision, to develop school development plans, to monitor the effectiveness of the educational process;

- to equip students with the theoretical material, practical skills and methods of educational management, the basis of the activity-based management, administrative management,

- to organize the school structure in an efficient manner, to monitor the execution of measures aimed at planning and arranging of educational process;

- to ensure the occupational quality of teachers and principals, staff professional becoming;

- to ensure the supervisory control over school and its structural subdivisions, to create the innovative organizational culture;

- to form ethical behavior of staff members, to create the comfortable environment and working conditions, to ensure staff' and students' moral and psychological commitments;

- to develop the students' abilities to manage the educational and economic activities of an educational institution, etc.

In this regard, it should be noted that unlike with Ukraine, in America there is a continuum of principal preparation programs but a one-size-fits-all approach to principal preparation is missing. Preparation programs vary widely in admission standards, program content, and innovativeness [5]. A four-year study by Arthur Levine, President of Teachers College at Columbia University, has found that a greater part of principal preparation programs "range from inadequate to appalling, even at some of the country's leading universities" [2].

The majority of the US university-based principal preparation programs comprised of the design elements aligned with seven key features of effective leadership preparation programs:

1) clear focus and values about leadership and learning around which the program is coherently organized,
2) standards-based curriculum emphasizing instructional leadership, organizational development, and change management,

3) field-based internships with skilled supervision,

4) cohort groups that create opportunities for collaboration and teamwork in practice-oriented situations,

5) active instructional strategies that link theory and practice, such as problem based learning,

6) rigorous recruitment and selection of both candidates and faculty, and

7) strong partnerships with schools and districts to support quality field-based learning [3, p. 8-15].

The majority of programs are tailored to address properly the challenges of school leadership in presentday schools [5]. In recent years, many universities have revised their principal preparatory programs in order to meet the needs of the changing environment in which schools operate. The well-known scientist Orr has identified five pillars of innovations in preparing school leaders:

- reinterpretation of leadership being a mainstay of the teaching and learning improvement;

- a new vision of designing the program content, pedagogy, and field-based learning experiences to be more powerful tool of preparing leaders;

- redesign of the doctorate as an intensive midcareer professional development activity; use of partnerships for richer, more extensive program design opportunities;

- a commitment for continuous improvement [9, p. 493-495].

According to Murphy, a greater part of the universities have revised the program design, content, and the methods of the program delivery and implementation [8]. Such scientists as K. Leithwood, D. Jantzi, G. Coffin and P. Wilson have revealed that redesigned programs are, to a great extent, related to the teacher-perceived leadership efficiency of graduates when the programs have a strong theoretical and research base, provided authentic field experiences, stimulated the development of situated cognition, and developed real-life problem-solving skills [7]. According to M. Orr, restating the organization principles is the brand new direction which is important for leadership preparation. In contrast with the traditional programs, which are quite incoherent, some new programs have been designed to clearly define visions and fundamental principles [9]. Such visions outline the ways of improving the principal preparation. Murphy's three new pillars of leadership have influenced the development of the innovative programs of principal preparation. The first pillar is "social justice leadership," which emphasizes that all students will reach proficiency, without exceptions or excuses, and principals should promote the school organization in the way which would advance the equitable learning of all students. The second is "leadership for school improvement" mainly focusing on the instructional leadership committed to the core business of teaching, learning and knowledge. The third is "democratic leadership," committed to building a school community that benefits all stakeholders and facilitates interactions between leaders [1]. According to Orr's research, many university-based preparation programs have been constructed on the basis of the above innovative ideas and strategies. For example, Portland State University, the US public research university, has implemented the coherent Master's program based on the reconceive foundational principles that define sustainable leadership. The second 
example is Marshall University which has implemented the innovative programs based on the self-assessment and reflection, and student portfolios. The third example is Florida State University, which program is aimed at renewal and improvement of schools and school systems. [1].

It is expedient, in our opinion, to consider that the customary approach to the US principal preparation is characterized by some drawbacks such as:

- lack of a competency profile. In all likelihood, programs often encapsulate a delinked set of components, which fail to develop the competencies required for a principal to work in an efficient manner. There is a plenty of principal preparation programs which fail to comply with the professional standards, to meet the requirements for license granting;

- recruitment failure. In most cases, it turns out that the principal preparation program alumni continue working as teachers, and have enrolled only to get an increase in pay. They obtain the master's degree in administration but have no intention of working as school administrators in future;

- inconsistent and irrelevant coursework which lacks practical mastery. The program components are not properly tailored, and do not team up with one another to compile a coherent program being in line with the competency framework required to prepare an innovative principal. Academic staff is often comprised of researchers lacking their own practitioner expertise. Moreover, the program material used is often outdated, and delivered from a theoretical perspective.

The National Staff Development Council has developed some recommendations for the principal preparation program content to be considered in the development of programs. They are as follows:
1) learn strategies that can be used to foster continuous school improvement;

2) understand how to build supportive school cultures that promote and support adult and student learning;

3) develop knowledge about individual and organizational change processes;

4) develop knowledge of effective staff development strategies;

5) understand important sources of data about their schools and students and how learn public engagement strategies, including interpersonal relationship skills $[4, \mathrm{p}$. $6]$.

Conclusions. Recently, the Ukrainian universities have become much more concerned about the development and implementation of the programs on preparing principals of innovative type which will meet the expectations of all stakeholders under the present-day conditions. The innovative principal preparation programs shall be designed to fulfill the vision reflecting in the national standards and develop principals with the knowledge, skills and features of an instructional leader, and the ability to give a boost to the internal and external school communities in support of increased academic attainment. Our appealing to the US experience is due to the fact that the United States is characterized by a diversity of the principal preparation programs varying widely in admission standards, program content, and innovativeness. In addition, the National Staff Development Council has developed some recommendations for the principal preparation program content which should be considered in the development of programs.

The study conducted does not resolve the totality of the above problems. The prospects of further research are to outline prospects for positive use of the US advanced ideas of the principal preparation in the domestic universities.

\section{REFERENCES}

1. Adkins, E. The Effectiveness of Principal Preparation ProgramType for Administrative Work. //Marshall University College of Education and Human Services. // Dissertation submitted to the faculty of the Marshall University Graduate College in partial fulfillment of the requirements for the degree of Doctor of Education in Educational Leadership, 2009.

2. Belzberg, L. Becoming a Nation of School Leaders. - [Electronic resource]. - Mode of access: http:// https://www.huffingtonpost.com/lisa-belzberg/becoming-anation-of-scho_b_798238.html

3. Davis, S., Darling-Hammond, L., LaPointe, M., Meyerson, D. School Leadership Study Developing Successful Principals. // Stanford: Stanford Educational Leadership Institute, 2005.

4. Darling-Hammond, L., LaPointe, M., Meyerson, D., Orr. M., Cohen, C. Preparing School Leaders for a Changing World: Lessons from Exemplary. // Stanford, CA: Stanford University, Stanford Educational Leadership Institute, 2007.

5. Hale, E., Moorman, H. Preparing School Principals: A National Perspective on Policy and Program Innovations. //
Washington D.C.: Institute for Educational Leadership, 2003.

6. Fry, B., Bottoms, G., O'Neill, K. The Principal Internship: How Can We Get It Right? // Atlanta : Southern Regional Education Board, 2005.

7. Leithwood, K., Jantzi, D., Coffin, G., Wilson, P. Preparing School Leaders: What Works? // Journal of School Leadership, 1996. Issue 6. P. 316-342.

8. Murphy, J. The Quest for the Center: Notes on the State of the Profession in Educational Leadership. // The University Council for Educational Administration. Columbia, MO, 2001.

9. Orr, M. Mapping innovation in leadership preparation in our nation's Schools of Education. // Phi Delta Kappan, 2006. Issue 87 (7). P. 492-499

10. Sparks, D., Hirsh, S. A National Plan for Improving Professional Development. // Oxford, OH: National Staff Development Council, 2000.

11. Peel, H., Buckner, K., Wallace, C., Wrenn, S., Evans, R. NASSP Bulletin, 1998. P. 26-34.

\section{Особенности украинского и американского опыта в подготовке руководителей школ инновационного типа} Д. А. Козлов

Аннотация. В статье рассматриваются особенности украинского и американского опыта подготовки руководителей школ инновационного типа. Определены семь ключевых особенностей эффективных программ подготовки руководителей школ. Автор акцентирует внимание на трех инновационных элементах руководства, разработанных американским ученым Мерфи, которые повлияли на разработку инновационных программ подготовки руководителей школы в США. Выявлены недостатки стандартного подхода к подготовке руководителей школы в США. Изложены некоторые рекомендации, разработанные Национальным советом по развитию персонала США в отношении основного содержания программы подготовки, которые должны быть учтены при разработке инновационных программ.

Ключевые слова: руководитель иколь, подготовка, американский опьлт, инновации, университет. 